Vol. 5 (1996): 413-419.

\title{
Effects of expanding on the nutritive value of wheat bran in pig diets
}

\author{
Matti Näsi, Kirsi Partanen and Pasi Laurinen \\ Department of Animal Science, P.O. Box 28, FIN-00014 University of Helsinki, Finland
}

\begin{abstract}
Nutrient digestibility and protein utilization responses in pigs to the expanding process of wheat bran were evaluated. The digestibility and nitrogen balance study was conducted with nine finishing barrows (live weight of $75-93 \mathrm{~kg}$ ) using a two-period reversal design with a $2 \times 2$ factorial arrangement of treatments. Wheat bran, untreated or expanded with a Kahl expander at a temperature of 105$110^{\circ} \mathrm{C}$, was included at two levels of 150 or $300 \mathrm{~g} \mathrm{~kg}^{-1}$ in barley-based diet supplemented with minerals and vitamins and fortified with lysine. The level of wheat bran in the diet had a diminishing effect on organic matter (OM), neutral detergent fibre (NDF), and hemicellulose (HC) digestibilities of the diet and tended to decrease those of crude protein $(\mathrm{CP})$ and ash. Expanding of the wheat bran affected a non-significant improvement on ether extract (EE), NDF, acid detergent fibre (ADF) and HC digestibilities of the diet. Nutrient digestibilities of wheat bran and expanded wheat bran computed by regression were $0.64,0.67$ for $\mathrm{OM} ; 0.70,0.70$ for $\mathrm{CP} ; 0.47,0.63$ for EE; $0.35,0.40$ for NDF and 0.01 , 0.16 for ADF, respectively. Feed values of untreated and expanded wheat bran were 11.45 and 12.08 MJ ME kg-1 DM, 7.84 and $8.02 \mathrm{MJ} \mathrm{NE} \mathrm{kg}^{-1} \mathrm{DM}$ and digestible crude protein 113 and $110 \mathrm{~g} \mathrm{~kg}^{-1} \mathrm{DM}$ respectively. The expanding process had no effect on nitrogen retention or protein utilization parameters measured. Processing of wheat bran with an expander had only a slight improving effect on the nutritive value of bran in pig diets.
\end{abstract}

Key words: cereal by-products, fibrous feeds, processing, digestibility, nitrogen balance

\section{Introduction}

Thermal pressure conditioning or expansion of compound feeds or feed ingredients is increasingly used in feed mills. With the expander, it is possible to achieve higher temperatures and pressures compared to conventional pelleting. The advantages of a combination of expander and pellet mill are claimed to be improved pellet quality and digestibility and an overall reduction of bulk density (Wettstein and Wild 1990). The beneficial effects of expanding also include elimination of antinutritional factors and improvement of hygienic quality of feeds. In addition, feed ingredients in liquid form can be used more easily in feed mixtures treated with an expander. The scientific information available con- 
Näsi, M. et al. Effects of expanding on the nutritive value of wheat bran

cerning the responses of expanding to nutritive value of various feed ingredients, especially fibrous by-products, is scarce. The improving effect of expanding on nutritive value of barley or wheat middlings in diets for growing pigs has, however, been limited (Näsi 1992, Laurinen et al. 1995, Siljander-Rasi et al. 1995).

Wheat bran is available as a feed ingredient at a reasonable price. Therefore it is tempting to add it to grower feeds for pigs in order to decrease feed costs. Wheat bran has a relatively high phytase activity which promotes its use in feed formulas for pigs in order to reduce phosphorus excretion in faeces (Helander et al. 1994). Wheat bran has a rather high content of dietary fibre which decreases digestibily of nutrients and protein utilization. The dietary inclusion of wheat bran should be restricted to not more than $40 \mathrm{~g} \mathrm{~kg}^{-1}$ added NDF to optimize the performance of growing pigs (Cromwell et al. 1992). The main dietary fibre components of wheat bran are pentosans or arabinoxylans. The arabinoxylan content of wheat bran ranges from 206 to $262 \mathrm{~g}$ $\mathrm{kg}^{-1}$ which makes the digestibility of the nutrients in bran low (Graham et al. 1986, BachKnudsen and Hansen 1991). The processing treatments of fibrous feedstuffs are carried out in order to rupture the cell wall matrix and to modify the chemical structure of the constituents to render them more susceptible to enzyme degradation in the small intestine, thus improving the digestibility and utilization of nutrients. It has also appeared to be an opportunity for cell wall degrading enzymes to improve the nutritional value of wheat bran for pigs (Inborr 1994).

The objective of the current study was to investigate the effects of the expanding process of wheat bran on nutrient digestibility and protein utilization in pigs fed barley based diets.

\section{Material and methods}

The digestibility and nitrogen balance experiment was conducted with nine castrated males
(Landrace $x$ Large White), with an initial weight of 74.6 (SE 2.54) $\mathrm{kg}$ and final weight of 92.6 (SE 2.42) kg using a two-period trial, in which the pigs were randomly allotted to the treatments. None of the pigs received the same diet twice. The experimental diets were arranged $2 \times 2$ factorially with two inclusion levels of wheat bran (150 and $300 \mathrm{~g} \mathrm{~kg}^{-1}$ ), either untreated or treated with the expanding process. The expanding of wheat bran was conducted with a Kahl expander at a temperature of $110^{\circ} \mathrm{C}$, and the pressure applied was 20 bar. The addition of steam was $50 \mathrm{~g} \mathrm{~kg}^{-1}$, half of which was applied through the inlet while the other half was injected in the barrel. The throughput of material was 10-12 tons per hour. The diets were barley-based supplemented with lysine $\left(2 \mathrm{~g} \mathrm{~kg}^{-1}\right)$, minerals and vitamins according to the recommendations of Salo et al. (1990). The pigs were fed twice daily according to a restricted feeding regime (2600 and $\left.2800 \mathrm{~g} \mathrm{~d}^{-1}\right)$. The daily ration was divided into two equal meals and mixed with water $(1: 1 \mathrm{w} / \mathrm{v})$ and between meals water was offered ad libitum.

During the whole experiment, the pigs were kept in metal metabolism cages equipped with collection trays, allowing separate collection of faeces and urine. Each period comprised of 5 days of adjustment and 5 days of total collection of faeces and urine. Total faeces were collected daily, stored at $-18^{\circ} \mathrm{C}$ until the end of the collection period, thawed and the composition was analysed. Urine was collected daily into 40 $\mathrm{ml}$ of $10 \mathrm{~N} \mathrm{H}_{2} \mathrm{SO}_{4}$ sampled, and stored at $4^{\circ} \mathrm{C}$ until the end of the trial when analyses of $\mathrm{N}$ and urea were carried out. The proximate composition of the feed ingredients were analysed using AOAC (1984) methods. The neutral and acid detergent fibre were analyzed according to Robertson and van Soest (1981). Two observations were excluded because of poor appetite of one pig during the first period and another pig because of vomiting during the second period. The other animals completed the experiment successfully and the average daily weight gain during the entire experiment was $720 \mathrm{~g}$. No differences in palatability of the variously treated wheat bran 
Vol. 5 (1996): 413-419.

in the diets were observed. Refusals of the diets were negligible.

The data were subjected to a least square analysis of variance (Snedecor and Cochran 1989) using the model $Y_{i j k}=\mu+A_{i}+P_{j}+T_{k}+$ $e_{i j k}$, where $A, P$ and $T$ are the effects of animal, period and treatment, respectively. To calculate the digestibility coefficients of nutrients in wheat bran the data were inserted into a multiple regression equation $\mathrm{Y}=\mathrm{aX} \mathrm{X}_{1}+\mathrm{bX}_{2}$, in which $\mathrm{Y}$ is the total amount of nutrients digested from the ratio $(\mathrm{g} / \mathrm{d}), \mathrm{X}_{1}$ and $\mathrm{X}_{2}$ are the amounts of nutrients consumed from barley and wheat bran $(\mathrm{g} / \mathrm{d})$, and $\mathrm{a}$ and $\mathrm{b}$ are the digestible fractions of nutrients in barley and wheat bran, respectively (Schneider and Flatt 1975). The metabolizable and net energy values of wheat bran were calculated according to Schiemann et al. (1972), CVB (1991) and Tuori et al. (1995).

\section{Results and discussion}

The chemical composition of the experimental feeds is given in Table 1. Only small differences and no systematic effects of treatment were found in the proximate composition of expander processed wheat bran compared with the untreated one (Table 1). This agrees with the previous results which revealed no systematic impact of expansion on chemical composition of barley or wheat middlings (Näsi 1992, Laurinen et al. 1995, Siljander-Rasi et al. 1995). Pressurized hydrothermal processing is expected to gelatinize starch and increase solubility of dietary fibre and decrease the content of insoluble dietary fibre (Fadel et al. 1988, Ralet et al. 1990).

The present treatment conditions were too mild to achieve a sufficiently strong processing effect on composition. The maximum temperature reached with addition of steam $(5 \%)$ during expansion was about $105-110^{\circ} \mathrm{C}$. However, major effects are usually obtained at temperatures over $130-140^{\circ} \mathrm{C}$ (Hancock 1992). The chemical composition of the present wheat brans was quite
Table 1. The chemical composition of the dietary ingredients $\left(\mathrm{g} \mathrm{kg}^{-1}\right)$.

\begin{tabular}{lrrr}
\hline & Barley & $\begin{array}{c}\text { Wheat } \\
\text { bran }\end{array}$ & $\begin{array}{c}\text { Expanded } \\
\text { wheat } \\
\text { bran }\end{array}$ \\
\hline Dry matter & 868 & 873 & 871 \\
Ash & 24 & 55 & 53 \\
Crude protein & 115 & 160 & 157 \\
Ether extract & 32 & 61 & 60 \\
Crude fibre & 60 & 102 & 98 \\
Nitrogen free extract & 769 & 623 & 633 \\
NDF & 215 & 399 & 405 \\
ADF & 51 & 108 & 113 \\
Hemicellulose & 164 & 292 & 292 \\
\hline
\end{tabular}

$\mathrm{NDF}=$ neutral detergent fibre, $\mathrm{ADF}=$ acid detergent fibre

similar to the average values given in feed tables (Tuori et al. 1995). On the other hand, depending on the origin and milling process, the chemical composition, especially the contents of starch and dietary fibre, may vary considerably. The average dry matter intake of the experimental diets was $86 \mathrm{~g} \mathrm{~kg}^{-1}$ metabolic body weight and there were no differences in the palatability of the two sources of wheat bran.

The apparent total tract digestibilities of the dietary nutrients are presented in Table 2. The level of wheat bran inclusion in the diet had a significant effect on digestibility of carbohydrates. Digestibilities of $\mathrm{OM}(\mathrm{P}<0.01)$, NDF $(\mathrm{P}<0.01)$ and hemicellulose $(\mathrm{P}<0.05)$ were significantly decreased in diets supplemented with $300 \mathrm{~g} \mathrm{~kg}^{-1}$ wheat bran compared to a lower inclusion level. Digestibilities of ash and crude protein also tended to be lower $(\mathrm{P}<0.1)$ in diets with a higher wheat bran addition level. The low digestibility of cellulose and hemicellulose of wheat bran has previously been demonstrated by Zoiopoulos et al. (1983), Stanogias and Pearle (1985) and Graham et al. (1986). The depressive effect of increasing the level of fibrous material on digestibility of all nutrients and fibre itself has been firmly established in several studies (Zoiopoulos et al. 1983, Roth and Kirchgessner 1984, Stanogias and Pearle 1985, Fernandez et al. 1986). 
Näsi, M. et al. Effects of expanding on the nutritive value of wheat bran

Table 2. Apparent faecal digestibility of experimental diets.

\begin{tabular}{|c|c|c|c|c|c|c|c|c|}
\hline \multirow[b]{2}{*}{ Level, g/kg } & \multicolumn{2}{|c|}{ Wheat bran } & \multicolumn{2}{|c|}{ Expanded bran } & \multirow[b]{2}{*}{ SEM } & \multicolumn{3}{|c|}{ Statistical significance ${ }^{1}$} \\
\hline & 150 & $300^{2}$ & 150 & $300^{2}$ & & $\begin{array}{l}\text { Bran vs } \\
\text { ex-bran }\end{array}$ & $\begin{array}{c}150 \mathrm{vs} \\
300\end{array}$ & $\begin{array}{c}\text { Inter- } \\
\text { actions }\end{array}$ \\
\hline Dry matter & 0.795 & 0.755 & 0.797 & 0.769 & 0.0031 & NS & $* *$ & NS \\
\hline Organic matter & 0.815 & 0.778 & 0.817 & 0.790 & 0.0031 & NS & $* *$ & NS \\
\hline Ash & 0.434 & 0.395 & 0.436 & 0.423 & 0.0077 & NS & o & NS \\
\hline Crude protein & 0.773 & 0.745 & 0.771 & 0.756 & 0.0064 & NS & o & NS \\
\hline Ether extract & 0.480 & 0.460 & 0.487 & 0.522 & 0.0111 & o & NS & NS \\
\hline NDF & 0.497 & 0.442 & 0.506 & 0.481 & 0.0078 & o & $*$ & NS \\
\hline ADF & 0.101 & 0.046 & 0.133 & 0.143 & 0.0195 & o & NS & NS \\
\hline Hemicellulose & 0.626 & 0.576 & 0.630 & 0.598 & 0.0049 & o & $* *$ & NS \\
\hline
\end{tabular}

$\mathrm{NDF}=$ neutral detergent fibre, $\mathrm{ADF}=$ acid detergent fibre, $\mathrm{SEM}=$ standard error of the mean,

$1 * * *=\mathrm{p}<0.001,{ }^{* *}=\mathrm{p}<0.01,{ }^{*}=\mathrm{p}<0.05, \mathrm{o}=\mathrm{p}<0.10$

${ }^{2}$ Due to the missing observations the SEM-values given should be multiplied by 1.0587 when making comparisons with other mean values.

The expanding treatment of wheat bran tended non-significantly to improve digestibilities of EE, NDF, HC and ADF, the magnitude being 2-6 $\%$-units. Similarly, low improvements of crude fibre, ADF and EE were found in piglets fed diets with wheat bran due to the expander process (Bolduan et al. 1993). Laurinen et al. (1995) also reported that expander processing increased digestibility of EE, while in contrast to these present results, the digestiblity of crude carbohydrates was decreased in diets composed of wheat middlings. The expanded hammer milled barley showed lower organic matter digestibility than without expanding (Näsi 1992). A stronger process, extrusion, of a diet containing wheat middlings has improved apparent total tract digestibility of $\mathrm{OM}$, but only to the same level as pelleting (Skoch et al. 1983), and also ileal digestibilities of DM, starch and CP (Fadel et al. 1988). Expanding did not improve digestibility of diet energy (Bolduan et al. 1993).

Hancock (1992) concluded that the expansion process of fibrous feedstuffs has similar effects to extrusion processing of starchy feeds; large molecules tend to be disrupted by shearing in treatment which increases digestibility. The efficacy of expander or extrusion processing to improve nutrient utilization from fibrous feedstuffs is dependent on the type of fibre and processing conditions, with processing temperatures below $120^{\circ} \mathrm{C}$ having a minimal effect on the nutritional value of dietary fibre. The results of the present study confirm the previously presented data that treatment employing rather low processing temperatures has a low impact in the improving nutritive value of resistant fibrous feedstuff, such as wheat bran.

The digestibilities of some nutrients calculated by the regression equation were slightly higher in expanded wheat bran than in untreated bran, $2.6 \%$-units for $\mathrm{OM}$, contributing to the enhancements of the constituents of EE 16.2, NDF 4 and ADF $15 \%$-units (Table 3). This improvement led to a little higher $(5 \%)$ calculated metabolizable energy contents. The net energy value for wheat products is calculated by an equation which is based on the chemical composition only (CVB 1991, Tuori et al. 1995) and the NE-value obtained was $2.3 \%$ higher in expanded wheat bran. The digestibility values for untreated wheat bran were close to the average values given in feed tables (Tuori et al. 1995). The results reported by Laurinen et al. (1995) are in accordance with the present results; expanding enhanced the digestibility of EE while the effect on other nutrients was negligible. 
Vol. 5 (1996): 413-419.

Table 3. Apparent faecal digestibility calculated by regression and feed value of the wheat brans.

\begin{tabular}{lrrr}
\hline & Barley' & $\begin{array}{c}\text { Wheat } \\
\text { bran }\end{array}$ & $\begin{array}{c}\text { Expanded } \\
\text { wheat bran }\end{array}$ \\
\hline Dry matter & $0.849 \pm 0.0104$ & $0.631 \pm 0.0366$ & $0.661 \pm 0.0312$ \\
Organic matter & $0.846 \pm 0.0100$ & $0.640 \pm 0.0362$ & $0.666 \pm 0.0314$ \\
Crude protein & $0.800 \pm 0.0310$ & $0.704 \pm 0.0706$ & $0.703 \pm 0.0759$ \\
Ether extract & $0.452 \pm 0.0286$ & $0.469 \pm 0.0553$ & $0.631 \pm 0.0432$ \\
NDF & $0.534 \pm 0.0314$ & $0.353 \pm 0.0577$ & $0.397 \pm 0.0520$ \\
ADF & $0.111 \pm 0.0584$ & $0.008 \pm 0.0899$ & $0.159 \pm 0.0875$ \\
Hemicellulose & $0.667 \pm 0.0236$ & $0.481 \pm 0.0475$ & $0.490 \pm 0.0389$ \\
FU/kg DM & 1.148 & & 0.862 \\
DCP/kg DM & 92 & 113 & 110 \\
DCP/FU & 80 & 139 & 128 \\
ME MJ/kg DM & 14.87 & 11.45 & 12.08 \\
NE MJ/kg DM & 10.67 & 7.84 & 8.02 \\
\hline
\end{tabular}

'Mean from two regression equations.

Nitrogen balance and protein utilization of the experimental diets are given in Table 4. The faecal $\mathrm{N}$ excretion was affected by the wheat bran supplementation level in the diet and by expander processing mainly due to different supplies of $\mathrm{N}$. The processing treatment or wheat bran inclusion level in the diet did not have any significant effect on $\mathrm{N}$ retention or protein utili- zation parameters measured. Similarly, Näsi (1992) reported that protein utilization responses in pigs was unaffected by the expanding process of barley. This is also in accordance with the data of Fadel et al. (1988) where a stronger process extrusion was empoyed. Inconsistent results of protein utilization has been reported by Laurinen et al. (1995) where the expander decreased

Table 4. Nitrogen metabolism and utilization in pigs fed on experimental diets.

\begin{tabular}{|c|c|c|c|c|c|c|c|c|}
\hline \multirow[b]{2}{*}{ Level, g/kg } & \multicolumn{2}{|c|}{ Wheat bran } & \multicolumn{2}{|c|}{ Expanded bran } & \multirow[b]{2}{*}{ SEM } & \multicolumn{3}{|c|}{ Statistical significance ${ }^{1}$} \\
\hline & 150 & $300^{2}$ & 150 & $300^{2}$ & & $\begin{array}{l}\text { Bran vs } \\
\text { ex-bran }\end{array}$ & $\begin{array}{c}150 \mathrm{vs} \\
300\end{array}$ & $\begin{array}{l}\text { Inter- } \\
\text { actions }\end{array}$ \\
\hline $\mathrm{N}$ intake, g/day & 46.1 & 48.7 & 46.0 & 48.4 & 0.03 & $* *$ & $* * *$ & $*$ \\
\hline Faecal N, g/day & 10.5 & 12.4 & 10.5 & 11.8 & 0.29 & NS & $*$ & NS \\
\hline $\mathrm{N}$ absorbed, g/day & 35.6 & 36.4 & 35.4 & 36.6 & 0.30 & NS & o & NS \\
\hline - of intake & 0.773 & 0.745 & 0.771 & 0.756 & 0.0064 & NS & o & NS \\
\hline Urinary N, g/d & 14.6 & 15.4 & 14.6 & 14.4 & 0.30 & NS & NS & NS \\
\hline $\mathrm{N}$ retention, g/d & 21.1 & 21.0 & 20.8 & 22.1 & 0.32 & NS & NS & NS \\
\hline - of intake & 0.455 & 0.431 & 0.453 & 0.458 & 0.0063 & NS & NS & NS \\
\hline - of absorbed & 0.589 & 0.578 & 0.588 & 0.607 & 0.0076 & NS & NS & NS \\
\hline - per kg W0.75 & 0.750 & 0.746 & 0.744 & 0.788 & 0.0110 & NS & NS & NS \\
\hline Urinary urea $\mathrm{N}, \mathrm{g} / \mathrm{d}$ & 10.6 & 11.5 & 10.8 & 10.5 & 0.32 & NS & NS & NS \\
\hline - per $\mathrm{kg} \mathrm{W}^{0.75}$ & 0.382 & 0.409 & 0.386 & 0.371 & 0.0119 & NS & NS & NS \\
\hline Biological value & 0.696 & 0.685 & 0.696 & 0.710 & 0.0072 & NS & NS & NS \\
\hline
\end{tabular}

' Table 2.

${ }^{2}$ Table 2 . 


\section{AGRICULTURAL AND FOOD SCIENCE IN FINLAND}

Näsi, M. et al. Effects of expanding on the nutritive value of wheat bran

$\mathrm{CP}$ digestibility without any effect on $\mathrm{N}$ retention nitrogen in one trial, but improved protein retention without any effect on CP digestibility in an other trial when expanded or untreated wheat bran and middligs were studied. In their experiment, $\mathrm{N}$ retention remained the same despite different steam additions in processing with the expander. In piglets, the N-balance has been improved when expanding the diet with wheat bran was compared to the untreated diet (Bolduan et al. 1993).

Acknowledgements. The authors are grateful to Mr. Juhani Vuorenmaa, M. Agr. Sc., for cooperation in processing of the experimental feeds. The financial support for this study was received from Suomen Rehu Oy.

\section{References}

AOAC 1984. Official methods of analysis. Association of Official Analytical Chemist, Arligton, Virginia. 1141 p. Bach-Knudsen, K.E. \& Hansen, I. 1991. Gastrointestinal implications in pigs of wheat and oat fractions. 1. Digestibility and bulking properties of polysaccharides and other major constituents. British Journal of Nutrition 65: 217-232.

Bolduan, G., Beck, M. \& Peisker, M. 1993. Expanderwirkung auf Ferkelrationen mit Weizenkleie. Kraftfutter 5/92: 229-232.

Cromwell, G.L., Stahly, T.S. \& Monegue, H.J. 1992. Wheat middlings in diets for growing- finishing pigs. Journal of Animal Science 70, Suppl. 1: 405.

CVB 1991. Veevoedertabel. Centraal veevoederbureau, Lelystadt, Netherlands. June 1991.

Fadel, J.G., Newman, C.W., Newman, R.K. \& Graham, H. 1988. Effects of extrusion cooking of barley on ileal and faecal digestibility of dietary components in pigs. Canadian Journal of Animal Science 68: 891-987.

Fernandez, J.A., Jorgensen, H. \& Just, A. 1986. Comparative digestibility experiments with growing pigs and adult sows. Animal Production 43: 127-132.

Graham, H., Hesselman, K., \& Åman, P. 1986. Influence of wheat bran and sugar beet pulp on the digestibility of dietary components in a cereal-based pig diet. Journal of Nutrition 116: 242-251.

Hancock, J.D. 1992. Extrusion processing in preparation of ingredients and diets for swine. Proc. Distillers Feed Conference. 47: 33-49.

Helander, E., Näsi, M. \& Partanen, K. 1994. Inclusion of wheat bran in barley-soybean meal diets with different phosphorus levels for growing-finishing pigs. I. Effects of nutrient digestibility and mineral balances in finishing pigs. Agricultural Science in Finland 3: 27-40.

Inborr, J. 1994. Supplentation of pig starter diets with carbohydrate-degrading enzymes - stability, activity and mode of action. Agricultural Science in Finland 3, Suppl. no. 2. 23 p. +5 app.

Laurinen, P., Valaja, J., Näsi, M. \& Smeds, K. 1995. Effect of expanding on nutritive value of barley and wheat bran in pig diets. Abstracts 46th Annual Meeting of the European Association of Animal Production. Prague. No 1:103.

Näsi, M. 1992. Effects of grinding, pelleting and expand- ing on nutritive value of barley in pig diets. Agricultural Science in Finland 1: 461-469.

Ralet, M.C., Thibault, J.F. \& Della Valle, G. 1990. Influence of extrusion cooking on the physico-chemical properties of wheat bran. Journal of Cereal Science 11:249259.

Robertson, J.B. \& van Soest, P.J. 1981. The detergent system of analysis and its application to food. In: James, W.D.T. \& Theander, O. (eds.). The analysis of dietary fibre in foods. Marcell Dekker, New York. p. 123-158.

Roth, F.X. \& Kirchgessner, M. 1984. Verdaulichkeit der Energie und Rohnăhrstoffe beim Schwein in Abhăngigkeit von Futterungsniveau und Lebendgewicht. Zeitschrift für Tierphysiologie, Tierernährung und Futtermittelkunde 51: 79-87.

Salo, M.-L., Tuori, M. \& Kiiskinen, T. 1990. Rehutaulukot ja ruokintanormit. (Feed tables and nutrient requirements) Helsinki. 70 p. (in Finnish).

Schiemann, R., Nehring, K., Hoffmann, L. Jentsch, W. \& Chudy, A. 1972. Energetische Futterbewertung und Energienormen. VEB Deutscher Landwirschaftsverlag, Berlin. 344 p.

Siljander-Rasi, H, Alaviuhkola, T., Suomi, K. \& Smeds, K. 1995. Effect of expanding of wheat by-product containing diets on performance of growing pigs. Abstracts 46th Annual Meeting of the European Association of Animal Production. Prague. No 1:103.

Schneider, B.H. \& Flatt, P.W. 1975. The evaluation of feeds trough digestibility evaluation. University of Georgia Press, Athens, Georgia. 423 p.

Skoch, E.R., Binder, S.F., Deyoe, C.E., Allee, G.L. \& Behnke, K.C. 1983. Effects of steam pelleting conditions and extrusion cooking on a swine diet containing wheat middlings. Journal of Animal Science 57: 929-935.

Snedecor, G.W. \& Cochran, W.G. 1989. Statistical methods. 8th ed. lowa University Press, Ames, lowa. 503 p. Stanogias, G.\& Pearce, G.R. 1985. The digestion of fibre by pigs 1 . The effects of amount and type of fibre on apparent digestibility, nitrogen balance and rate of passage. British Journal of Nutrition 53: 513-530.

Tuori, M., Kaustell, K., Valaja, J., Aimonen, E., Saarisalo, E. \& Huhtanen, P. 1995. Rehutaulukot ja ruokintasuositukset. (Feed tables and nutrient recommendations) Yliopistopaino Helsinki. 99 p. (in Finnish). 
Vol. 5 (1996): 413-419.

Wettstein, A. \& Wild, R. 1990. Developments in feed production technology. Roche Symposium on Animal Nutrition and Health. Basel. p. 89-108.

Zoiopoulos, P.E., English, P.R. \& Topps, J.H. 1983.
Fibrous agro-industrial by-products as protein sources for bacon pigs. 1. Assesment of performance, digestibility and carcass quality. Zeitschrift fur Tierphysiologie, Tierernăhrung und Futtermittelkunde 49: 210-218.

\title{
SELOSTUS
}

\section{Ekspanderkäsittelyn vaikutus vehnänleseen rehuarvoon lihasian ruokinnassa}

\author{
Matti Näsi, Kirsi Partanen ja Pasi Laurinen \\ Helsingin yliopisto
}

Tutkimuksessa selvitettiin ekspanderkäsittelyn vaikutusta lihasioille syötettävän vehnänleseen ravintoaineiden sulavuuteen ja valkuaisen hyväksikäyttöön. Tutkimus tehtiin $2 \times 2$ faktorikokeena $75-93$ kg elopainoisilla lihasioilla. Vehnänlese käsiteltiin Kahlekspanderilla, jolloin tuotteen lämpötila nousi 105$110^{\circ} \mathrm{C}$ :een. Ohrapohjaiseen rehuseokseen lisättiin 150 tai $300 \mathrm{~g} \mathrm{~kg}^{-1}$ joko ekspandoitua tai käsittelemätöntä vehnänlesettä. Prosessointi ei vaikuttanut leseen kemialliseen koostumukseen. Vehnänleseen lisäystaso vaikutti dieetin ravintoaineiden, varsinkin kuitujakeiden, sulavuuksia alentavasti. Ekspander-käsittely puolestaan paransi lievästi dieetin ravintoaineiden sulavuutta. Prosessoidun vehnänleseen raakarasvan $(0,63$ vs. 0,47$)$ ja happodetergenttikuidun $(0,01$ vs $0,16)$ sulavuudet olivat korkeampia kuin käsittelemättömän leseen. Ekspandoidun vehnänleseen rehuyksikköarvoksi saatiin $0,862 \mathrm{~kg}^{-1}$ kuiva-ainetta ja vastaavasti käsittelemättömälle $0,843 \mathrm{ry} \mathrm{kg}^{-1}$ kuiva-ainetta. Ekspanderkäsittely ei vaikuttanut valkuaisen hyväksikäyttöön typpitaseparametrien perusteella arvioituna. Tutkimuksen perusteella ekspanderprosessointi parantaa vain hyvin vähän vehnänleseen rehuarvoa, mikä tukee aikaisempia tutkimustuloksia muiden rehuraaka-aineiden ekspandoinnista. 